\title{
SANITARY QUALITY OF BROILER LITTER REUSED
}

Doi:http://dx.doi.org/10.1590/1809-4430-Eng.Agric.v35n5p800-807/2015

\section{MARIA DE F. A. VIEIRA ${ }^{1}$, ILDA DE F. F. TINOCO², BERNADETE M. DOS SANTOS ${ }^{3}$, KELES R. A. INOUE ${ }^{4}$, MÚCIO A. DOS S. A. MENDES ${ }^{5}$}

\begin{abstract}
Considering the importance of the substrate to bedding in the poultry industry in Brazil, and the enormous pressure on environmental management as to the correct use and management of the waste generated by the production sector, this study aimed to analyze the effect of reuses of two types of litter on sanitary qualities and productive performance of broilers. The study was conducted with litter from 32 different broiler houses, two types of substrates and four cycles of reuses. The litter sanitary quality was verified by the identification of the presence of Escherichia coli and Salmonella spp. and the incidence of footpad dermatitis. It was observed that the coffee hulls litter presented a reduction of 28.61 percentage points in the probability of occurrence of Salmonella spp when compared to the wood shavings litter, nevertheless, no statistical difference was observed on bacterial occurrence with Salmonella spp. for litter of different types or numbers of reutilization. The presence of Escherichia coli was detected in litter of all cycles, for both types of substrate. The occurrence of footpad lesions was detected for both types of litter, and was influenced by the number of reutilization cycles of the litter. The degree of incidence was detected only for the litter with coffee hull in which there was an increase of $30 \%$ between the first and second reuse from which tended to stabilize.
\end{abstract}

KEYWORDS: Salmonella spp., E. coli, footpad, productive performance.

\section{QUALIDADE SANITÁRIA DE CAMAS DE FRANGO DE CORTE REUTILIZADAS}

RESUMO: Considerando a importância do substrato para cama na avicultura industrial do Brasil e a enorme pressão relativa à gestão ambiental quanto ao correto emprego e manejo dos resíduos gerados pelo setor produtivo, buscou-se analisar o efeito das reutilizações de dois tipos de substratos de cama na qualidade sanitária e no desempenho produtivo dos animais. A pesquisa foi realizada em 32 aviários no Estado de Minas Gerais, e dois tipos de substratos e quatro ciclos de reutilização foram analisados. A qualidade sanitária da cama foi avaliada pela identificação das bactérias Escherichia coli e Salmonella spp., e incidência de dermatites no coxim plantar. Verificou-se que a cama de casca de café apresentou redução de 28,61 pontos percentuais na probabilidade de ocorrência de Salmonella spp quando comparada com a cama de maravalha, porém não houve diferença significativa entre os ciclos de reutilização das mesmas. Observou-se presença de Escherichia coli em todos os ciclos de reutilização das camas, em ambos os substratos. Houve ocorrências de lesões do coxim plantar para as camas avaliadas, sendo que, somente para a cama de casca de café, o número de reutilizações influenciou na incidência dessas lesões, aumentando $30 \%$ entre o primeiro e o segundo ciclos de reutilização a partir do qual houve tendência à estabilização.

PALAVRAS-CHAVE: Salmonella spp., E. colli, Lesões, desempenho produtivo

\footnotetext{
${ }_{1}^{1}$ Zootecnista, Mestre, Departamento de Engenharia Agrícola, Viçosa, MG, (31)91595940, fatimaraujo.vieira@gmail.com

${ }^{2}$ Eng $^{\mathrm{a}}$ Agrícola, Profa. Doutora, Departamento de Engenharia Agrícola, Viçosa, MG, iftinoco@ufv.br

${ }^{3}$ Médica Veterinária, Profa. Doutora, Departamento de Veterinária, Viçosa, MG, bmsantos@ufv.br

${ }^{4}$ Eng $^{\text {a }}$ Agrônoma, Doutora, Departamento de Engenharia Agrícola, Viçosa, MG, kelesregina@ hotmail.com

${ }^{5}$ Eng ${ }^{\circ}$ Agrícola, Mestre, Departamento de Engenharia Agrícola, Viçosa, MG, mucioandre@ gmail.com 


\section{INTRODUCTION}

The Brazilian poultry industry is one of the biggest in the world, being the country's third largest producer and exporter of chicken meat (UBA, 2012). With all this growth in the industry, the environmental aspect has its importance since in the productive chain generates waste. These residues represent losses of raw materials and energy, requiring significant investments in treatments to control pollution. Therefore, reducing the volume of waste and pollution load generated in the process, has proved of fundamental importance from the aspect of environmental management of farms (GONÇALVES et al., 2013).

In this sense, the litter reuse in several cycles of broiler production contributes to reduce waste volume minimizing possible impacts in the environment. However for litter reuse with sanitary security, this should be subjected to appropriate treatments in order to ensure the reduction of microbiological risks and environmental sustainability.

Among these treatments is highlighted the composting, started in the broiler houses and held during cycles of reuse and finalized when the litter is removed from the aviary and arranged in windrows for full aerobic treatment. This process accelerates the decomposition of organic matter compared to what would occur in the environment, improving the conditions of micro-organisms activity (ORRICO JÚNIOR et al, 2009;. 2010).

However, it is important to know if the sanitary conditions of reused litter are housed favorable for chickens especially with regard to pathogens such as salmonella and Escherichia coli (E. coli).

Infections caused by E. coli are responsible for economic losses in the poultry industry with colibacillosis often associated with poor feed conversion, lower body development and drug costs as well as increased carcass condemnation due to coli-septicemia injuries (BARROS et al., 2012).

Given the above this study aimed to analyze the effect of reuses of two types of substrates on sanitary quality of the litter and the productive performance of the animals.

\section{MATERIALS AND METHODS}

Broiler litter samples were collected on 35 to 45 days of bird life in 32 aviaries representing the regional poultry in the State of Minas Gerais, i.e. broiler houses with 12-14 meters wide, ceiling height of 2.8 to 3.2 meters, 100 to 120 meters length, fiber cement roof, average housing density of 14 to 18 birds $\mathrm{m}^{-2}$. In the aviaries there were tubular feeders and drinkers, positive pressure ventilation system, fitted with sidewalls curtains and axial fans disposed on the sides of them. Two different substrate types (coffee hull and thin wood shaving as they are the most used in the region), were evaluated during the four cycles of use. Each cycle represents the number of batches of birds reared on the substrate. Sampling was carried out from December 2010 to January 2011.

For each cycle of litter reuse, the data were collected in four aviaries totaling 32 wherein 16 of these were used coffee hull and the other 16, wood shaving as littering substrate. The collections were made in representing point in all housing area (Figure 1) been avoided the area near or below the feeders and drinkers according to the methodology used by SINGH et al. (2004). Each collecting sample point of the litter corresponded to a circle of approximately $20 \mathrm{~cm}$ radius and 7 $\mathrm{cm}$ high being removed with the help of auger and paddle. Sixteen single samples were collected from each aviary from where four composite samples were obtained, uncompressed, homogenized and packed in polyethylene bags properly identified. 


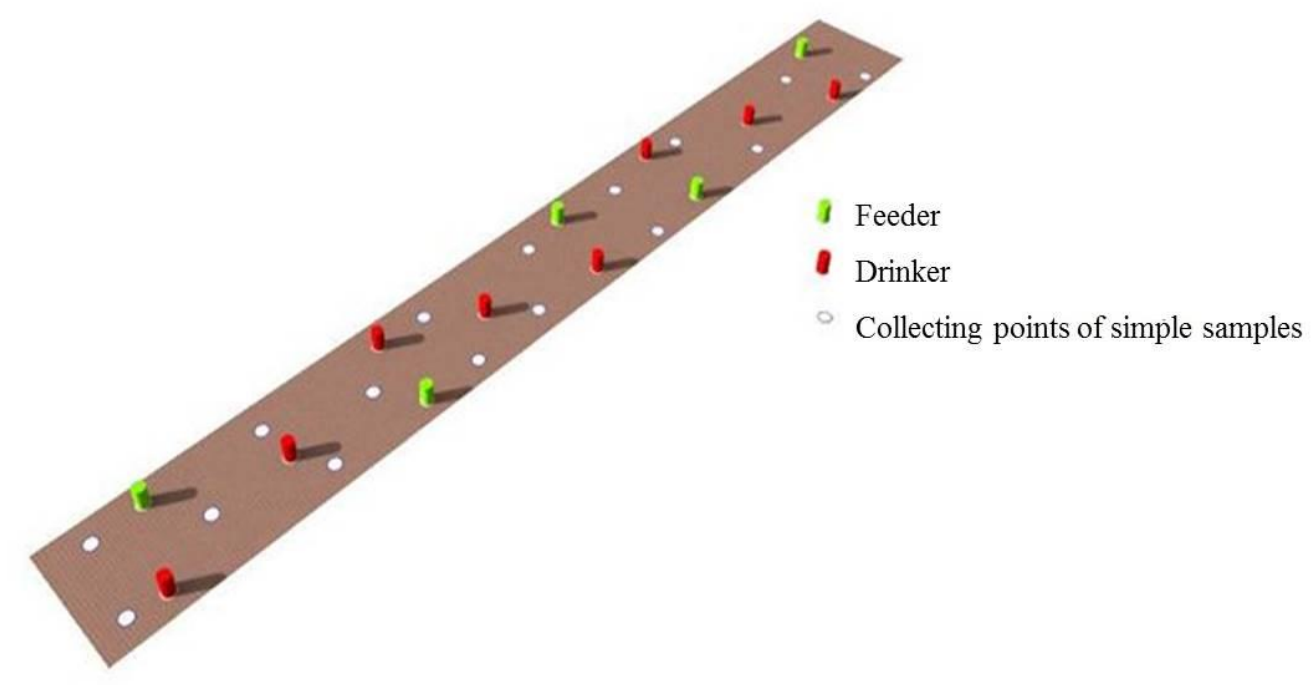

FIGURE 1. Selected points to collect simple samples of broilers litter.

To analyze the effect of reuses of two substrates in sanitary litter quality and productive performance, the following characteristics were evaluated: 1$)$ of the litter : $\mathrm{pH}$, moisture, E. coli and Salmonella spp; 2)of the birds: daily weight gain, feed conversion, mortality and presence of footpad dermatitis. The analyzes were conducted and their methods are described below.

The $\mathrm{pH}$ measurement was performed according to the methodology described by CAMARGO \& VALADARES (1980) using digital potentiometer bench (Quimis model Q 400 A, accuracy of $0.02 \pm 0.02 \mathrm{pH})$.

The moisture determination was carried out following the methodology described by EMBRAPA (1997).

Identification of bacteria (E. coli and Salmonella spp) was performed at the Laboratory of Bacteriology of the Unit of Study on Avian Health (UESA) Department of Veterinary Medicine, Universidade Federal de Viçosa, by multiple tube method using the procedure described by APHA (2005). Positive samples for E. coli were classified into four levels of intensity, according to the colonies growth in Petri dishes containing agar EMB in the following ways: a) Level 1, in which there was bacteria growth, but occupy only $1 / 4$ of the plate; b) Level 2, a little more intense growth, occupying $2 / 4$ of the plate; c) Level 3, even more intense growth, coming to occupy $3 / 4$ of the plate and d) Level 4, characterized by the maximum growth of bacteria occupying the entire Petri dish. The productive performance (average daily weight gain and feed conversion), as well as the mortality rate of the broiler was examined throughout the rearing period for the treatments evaluated. The values obtained were compared to the average performance indices of the animals, according to the Cobb international lineage table, on 42 days of age (COBB, 2012).

To evaluate the incidence of lesions in the footpad, visual evaluation were performed on $5 \%$ of the housed broiler in each aviary. Birds were randomly chosen inside the broiler house and have been evaluated only the presence or absence of lesions.

The experiment was conducted according to a completely randomized design (CRD). The statistical analysis of productive performance of the broiler and the presence of the footpad dermatitis was held on the SAEG® (System for statistical analysis) software, in which the data were checked by variance analysis (ANOVA) and means were compared using the Tukey test at 5\% probability.

The statistical analysis used to explain the probability of occurrence of Salmonella spp in the litter samples and identify determinants was carried out using the STATA/SE 11.0, and the logit 
model in which the dependent variables were based on the presence or absence of these bacterium. The type, the $\mathrm{pH}$ and the litter moisture were used in the model.

The analysis of the occurrence of Escherichia coli in broiler litter samples was presented in a descriptive way, due to no sufficient results for statistical analysis.

\section{RESULTS AND DISCUSSION}

\section{The productive performance evaluation and the presence of footpad dermatitis}

The reuse of coffee hull litter (Table 1) and wood shavings litter (Table 2) did not influence the results of productive performance $(\mathrm{P}>0.05)$.

TABLE 1. Mean values of productive performance - feed conversion (FC), daily weight gain (DWG), mortality (Mort) and footpad lesions (Cal) for the different cycles of reuse of coffee hulls litter (first, second, third and fourth use).

\begin{tabular}{lcccc}
\hline \multirow{2}{*}{ Treatment } & \multicolumn{4}{c}{ Variables } \\
\cline { 2 - 5 } & $\mathrm{FC}$ & $\begin{array}{c}\text { DWG } \\
(\mathrm{g})\end{array}$ & $\begin{array}{c}\text { Mort } \\
\left(\mathrm{n}^{\mathbf{0}} \text { birds }\right)\end{array}$ & $\begin{array}{c}\text { Cal } \\
(\%)\end{array}$ \\
\hline $1^{\text {st }}$ cycle of litter use & $1.88 \mathrm{~A}$ & $59.9 \mathrm{~A}$ & $4.6 \mathrm{~A}$ & $60 \mathrm{~B}$ \\
\hline $2^{\text {nd }}$ cycle of litter use & $1.92 \mathrm{~A}$ & $59.7 \mathrm{~A}$ & $4.4 \mathrm{~A}$ & $90.3 \mathrm{~A}$ \\
\hline $3^{\text {rd }}$ cycle of litter use & $1.86 \mathrm{~A}$ & $59.7 \mathrm{~A}$ & $5 . \mathrm{A}$ & $77.7 \mathrm{AB}$ \\
\hline $4^{\text {th }}$ cycle of litter use & $1.83 \mathrm{~A}$ & $62.8 \mathrm{~A}$ & $5.1 \mathrm{~A}$ & $69.3 \mathrm{AB}$ \\
\hline Means followed by the same letter in the column do not differ by Tukey test at $5 \%$ level of probability.
\end{tabular}

Means followed by the same letter in the column do not differ by Tukey test at $5 \%$ level of probability.

The frequency of coffee hull reuse litter influenced the incidence of footpads lesions on birds with difference of 10 to $30 \%$ among the different cycles of reuse $(60 ; 90.3 ; 77.7$ and $69.3 \%$, respectively), thus verifying increased incidence of these lesions by reusing litter. A similar result was found by SANTOS (2009) working with new litter and reused ones from coffee hulls noted that broilers reared on reused litter showed higher rates of injuries in the first phase of poultry production cycle (heating phase).

TABLE 2. Mean values of productive performance - feed conversion (FC), daily weight gain (DWG), mortality (Mort) and footpad lesions (Cal) for the different cycles of reuse of wood shavings litter (first, second, third and fourth use).

\begin{tabular}{lcccc}
\hline \multirow{2}{*}{ Treatment } & \multicolumn{4}{c}{ Variables } \\
\cline { 2 - 5 } & FC & $\begin{array}{c}\text { DWG } \\
(\mathrm{g})\end{array}$ & $\begin{array}{c}\text { Mort } \\
\left(\mathrm{n}^{\circ} \text { birds }\right)\end{array}$ & $\begin{array}{c}\text { Cal } \\
(\%)\end{array}$ \\
\hline $1^{\text {st }}$ cycle of litter use & $1.8 \mathrm{~A}$ & $59.2 \mathrm{~A}$ & $6.6 \mathrm{~A}$ & $63 \mathrm{~A}$ \\
\hline $2^{\text {nd }}$ cycle of litter use & $1.8 \mathrm{~A}$ & $58.0 \mathrm{~A}$ & $4.8 \mathrm{~A}$ & $67 \mathrm{~A}$ \\
\hline $3^{\text {rd }}$ cycle of litter use & $1.9 \mathrm{~A}$ & $58.9 \mathrm{~A}$ & $5.2 \mathrm{~A}$ & $60.5 \mathrm{~A}$ \\
\hline $4^{\text {th }}$ cycle of litter use & $1.9 \mathrm{~A}$ & $59.6 \mathrm{~A}$ & $5.9 \mathrm{~A}$ & $44.5 \mathrm{~A}$ \\
\hline
\end{tabular}

Means followed by the same letter do not differ by Tukey test at $5 \%$ level of probability.

However, for the second phase of broiler production cycle, the results of this study disagree with those obtained by SANTOS (2009), who observed a lower rate of injuries on footpads on broiler reared on reused litters.

Although some studies (TRALDI et al, 2004;. SANTOS, 2009), show the best results for the evaluation on broiler footpads on reused litter, in the present study, the coffee hulls litter in the first cycle of reuse provided better results presenting smaller percentage of these injuries. 
The reuse of wood shavings litter did not affect $(\mathrm{P}>0.05)$ the results of incidence in footpad lesions. These results differ from those found by TRALDI et al. (2007), who found that the scores of lesions on footpad and knee were higher in chickens reared on new wood shavings litter than those reared on reused ones.

\section{Analysis of the sanity quality on the litters}

\section{Salmonella spp occurrence}

It can be seen that in the model Logit (Table 3) the statistical likelihood ratio (LR) was significant $(\mathrm{P}<0.01)$, indicating that the presence of Salmonella spp is influenced by different types of materials used as litter substrate.

TABLE 3. Estimate results of Salmonella presence for different cycles of reusing, humidity (Um) and $\mathrm{pH}$ of coffee hulls and wood shavings litter.

\begin{tabular}{llll}
\hline \multicolumn{3}{c}{ Dependent variable: Salmonella spp } \\
\hline Variable & Coefficient & Standard Deviation & EM \\
\hline Litter & $-2.258495^{*}$ & 0.644935 & $-0.2861268^{*}$ \\
$\mathbf{N}^{\mathbf{*}}$ of cycles & $0.0418686^{\mathrm{ns}}$ & 0.2277788 & $0.005066^{\mathrm{ns}}$ \\
Um & $0.0929666^{*}$ & 0.0374016 & $0.0112488^{*}$ \\
ph & $0.361731^{\mathrm{ns}}$ & 0.4560713 & $0.0437687^{\mathrm{ns}}$ \\
Constant & -6.476415 & 3.920802 & \\
\hline
\end{tabular}

$L R=-52.98$

$\chi^{2}=17.58^{*}$

Count $R^{2}=82.03 \%$

$P\left(y_{\text {sal }}=1\right)=0.14083151$

* Significant at $1 \%,{ }^{\mathrm{ns}}$ not significant

Individual analysis of estimated coefficients shows that different types of substrates used as litter and the humidity of the same, influenced the presence of Salmonella spp $(\mathrm{P}<0.01)$. The other variables included in the model did not affect $(\mathrm{P}>0.05)$ in the occurrence of this bacterium. These results indicate that the incidence of Salmonella spp in the litters is independent of the ones of reusing cycle, being more related to the type of substrate.

In general, the probability of Salmonella occurrence in broiler litter, estimated by the model, $\mathrm{P}$ $\left(\mathrm{Y}_{\mathrm{sal}}=1\right)$ is about $14.08 \%$ due to the average values of the analyzed characteristics. However, changing the litter from wood shavings for coffee hull, led to a decrease of 28.61 percentage points (p.p) in the probability of Salmonella spp occurrence. The results indicate that the coffee hull litter provides sanitation conditions with respect to Salmonella spp., more appropriate in relation to wood shavings litter.

With regard to litter moisture, it can be seen that an increase of $1 \%$ in it, provides an increase of 11.25 percentage points (p.p) in the probability of occurrence of Salmonella spp in this litter.

The litter moisture when combined with high values of air temperature, is one of the determinants factors for increasing microbial growth. According to DAI PRA et al. (2009), the moisture rate on the litter should not generate excessive dust or retain much moisture to hinder the micro-organisms proliferation.

\section{E. coli. occurrence}

It can be seen that there is occurrence of positive results for Escherichia coli (E. coli), in virtually all litter samples independent of the use cycle and the type of substrate, wood shavings (Figure 2) and coffee hulls (Figure 3). 


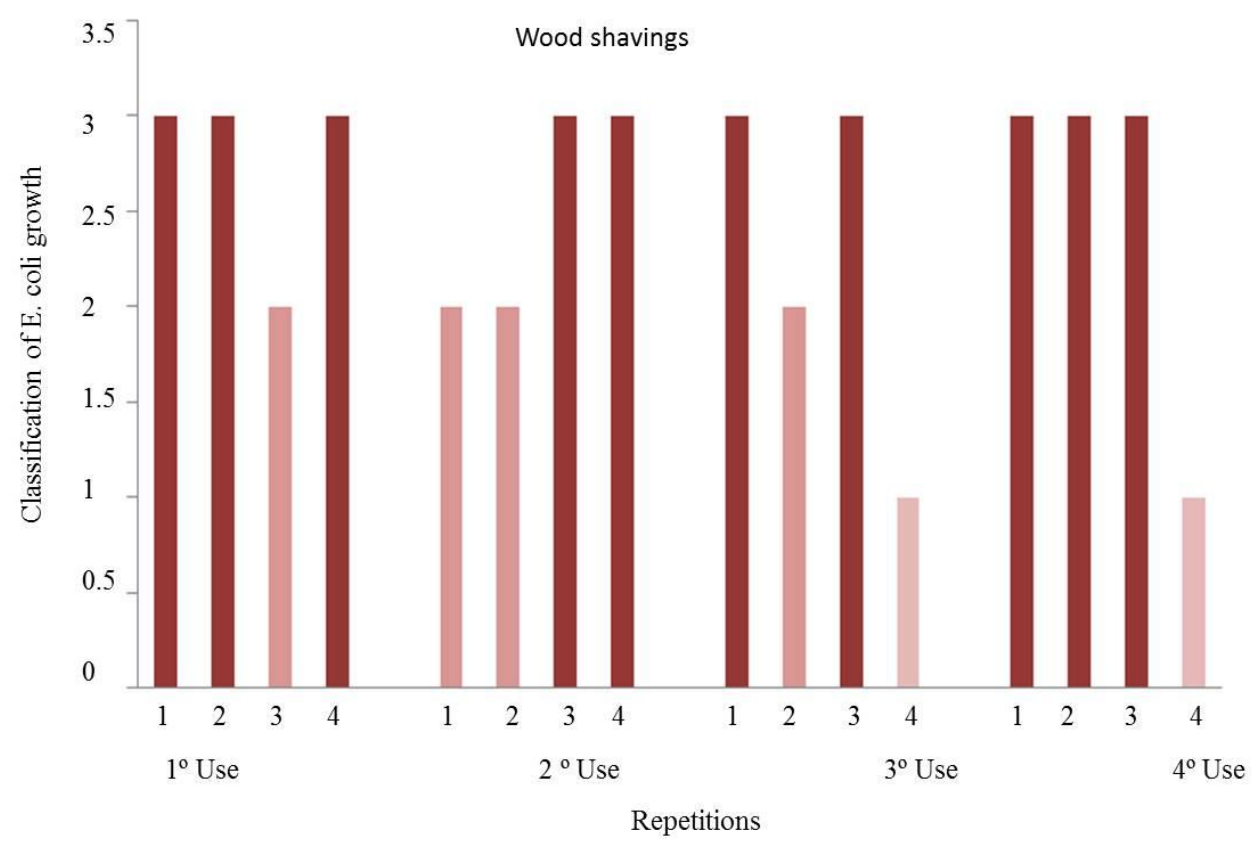

FIGURE 2. Distribution and classification of E. coli growth in different cycles of reuse of wood shavings litter.

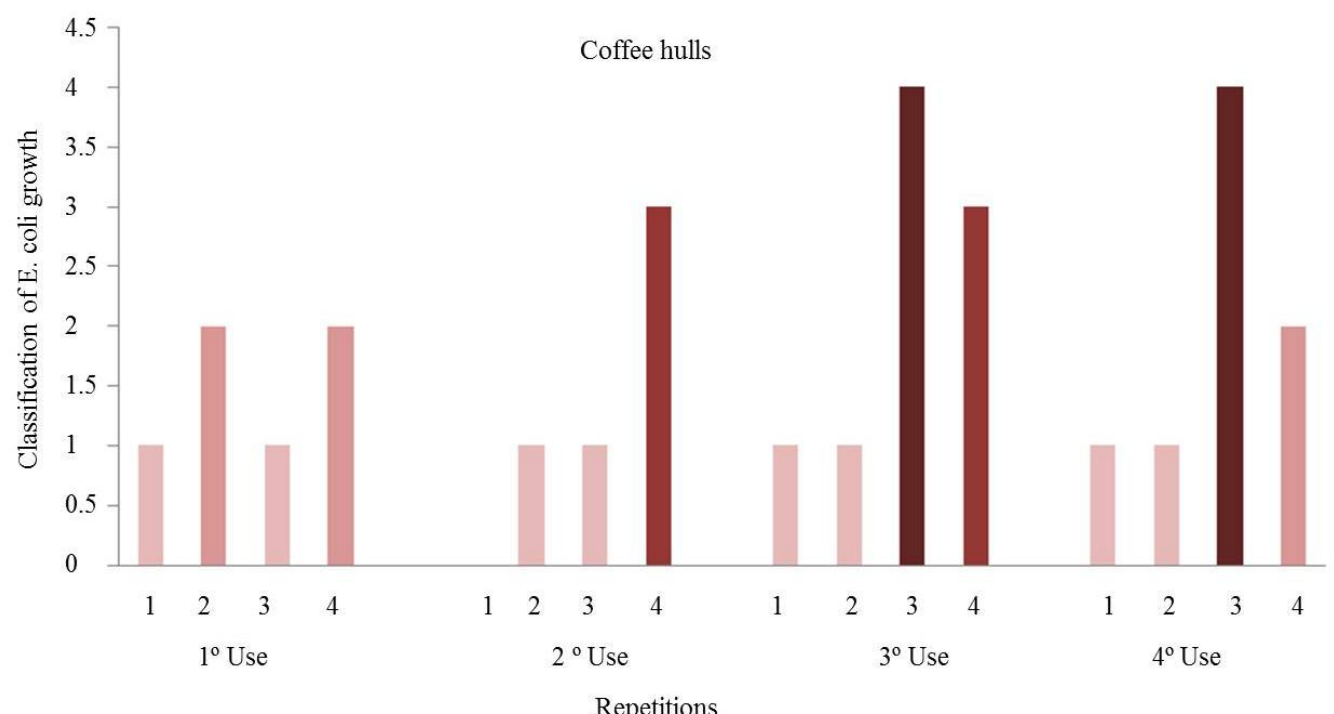

FIGURE 3. Distribution and classification of E. coli growth in different cycles of reuse of coffee hulls litter.

In wood shavings litter samples (Figure 2) predominated the growth on level 3 at the expense of others for all reuse cycles.

For coffee hulls litter can be observed an increase in intensity of growth on $E$. coli, in relation to using cycles (Figure 3 ). There was higher occurrence of growth on the $3^{\text {rd }}$ and $4^{\text {th }}$ cycles of reuse litter. In the environment, $E$. coli can persist for long periods particularly under conditions of low humidity, being conveyed in broiler through food, water and rodents (BARNES et al., 2003). This fact contributed to the occurrence of $E$. coli in all litter types, independent of the reuse cycle as observed in the present study. According to HANN et al. (2012), the population of micro-organism in poultry litter is highly variable depending especially of the sanitary management adopted. 


\section{CONCLUSIONS}

It was found that the coffee hulls litter decreased by 28.61 percentage points in the probability of Salmonella spp occurrence when compared with wood shavings litter but there was no significant difference between the reuse cycles of them. The presence of Escherichia coli was observed in all cycles of reuse litters in both substrates. There were instances of footpad lesions for the evaluated litters and only for coffee hulls litter the number of reuses influenced the incidence of these injuries, increasing $30 \%$ between the first and second reuse cycle from which there was tendency towards stabilization.

\section{REFERENCES}

APHA - American Public Health Association; AWWA - American Water Works Association; WEF - Water Environment Federation. Standard methods for the examination of water and wastewater. $21^{\text {th }}$ ed. Washington, 2005. 1268p. BARNES, H. J.; VAILLANCOURT, J.P.; GROSS, W.B. Colibacillosis. In: SAIF, Y. M.; BARNES, H.J; FADLY, A.M; GLISSON, J.R; MCDOUGALD, J.R; D. E. SWAYNE, D.E. (Ed.) Diseases of poultry. $11^{\text {th }}$ ed. Ames: Iowa State University Press, 2003. P. 631-656.

BARROS, L.S.S.; SILVA, R.M.; SILVA, I.M.M.; BALIZA, M.; FREITAS, F. A Avicultura brasileira e sua afinidade com a celulite aviária. Arquivos de Pesquisa Animal. Cruz das Almas, v.1, n.2, p.78-97, 2012.

BARNES H.J.; VAILLANCOURT, J.P.; GROSS, W.B. Colibacillosis. In: SAIF Y.M. (E.d). Diseases of poultry. Ames: Iowa State, 2003. p. 631-656.

CAMARGO, O.A.; VALADARES, J.M.A.S. Comportamento do manganês em Oxisol influenciado pela aplicação de carbonato de cálcio e sacarose. Revista Brasileira de Ciência do Solo, Viçosa, MG, v. 4, n.2, p.71-75, 1980.

COBB VANTRESS. Suplemento: desempenho e nutrição para frangos de corte. 2012. Disponível em: http://www.cobb-vantress.com. Acesso em: 20 jan. 13.

DAI PRA, M.A.; CORRÊA, E.K.; ROLL, V.F.; XAVIER, E.G.; LOPES, D.C.N.; LOURENÇO, F.F.; ZANUSSO, J.T.; ROLL, A.P. Uso de cal virgem para o controle de Salmonella spp. e Clostridium spp. em camas de aviário. Ciência Rural, Santa Maria, v. 39, n. 4, p. 1189-1194, Jul. 2009.

EMBRAPA. Empresa Brasileira de Pesquisa Agropecuária. Centro Nacional de Pesquisa de Solos. Manual de métodos de análise de solos. 2.ed. Rio de Janeiro, 1997. 212p.

GONÇALVES, M.S.; KUMMER, L.; RUTHES, J.M.; ROZA, D.A. Caracterização de cama de frangos e perus visando o manejo adequado de resíduos avícolas. In: SYMPOSIUM ON AGRICULTURAL AND AGROINDUSTRIAL WASTE MANAGEMENT; 3., 2013, São Pedro. Anais... São Pedro, SP, Brasil, 2013.

HAHN, L; PADILHA, M.T.S.; PADILHA, J.C.F.; POLI, A.; RIEFF, G.G. Persistência de patógenos e do antibiótico salinomicina em pilhas de compostagem de cama de aviário. Archivos de Zootecnia. Córdoba, v.61, n. 234, p. 279-285, jun. 2012. Disponível em:

<http://scielo.isciii.es/scielo.php?pid=S0004-05922012000200012\&script=sci_arttext>. Acesso em: 23 jan. 2013.

ORRICO JÚNIOR, M.A.P.; ORRICO, A.C.A.; LUCAS JÚNIOR, J. Compostagem da fração sólida da água residuária de suinocultura. Engenharia Agrícola, Jaboticabal, v.29, n.3, p.483-491, 2009.

ORRICO JÚNIOR, M.A.P.; ORRICO, A.C.A.; LUCAS JÚNIOR, J. Biodigestão Anaeróbia dos resíduos da produção avícola: Cama de frangos e carcaças. Engenharia Agrícola, Jaboticabal, v.30, n.3, p.546-554, 2010. 
SANTOS, C.R. Cama de casca de café tratada com condicionadores químicos e sua influência na qualidade do coxim plantar de frangos de corte. 2009. 69 f. Tese (Doutorado - Engenharia Agrícola) - Departamento de Engenharia Agrícola, Universidade Federal de Viçosa, Viçosa, 2009.

SINGH, A.; BICUDO, J.R.; TINÔCO, A. L.; TINÔCO, I.F.F.; GATES, R.S.; CASEY, K.D.; PESCATORE, AJ. Characterization of nutrients in built-up broiler litter using trench and random walk sampling methods. Journal of Applied Poultry Research, Champaign, v. 13, n.3 p. 426-432, 2004.

TRALDI, A.B.; OLIVEIRA, M.C.; GRAVENA, R.A. Avaliação das características da cama reutilizada e das lesões de peito, joelho e coxim plantar em frangos de corte consumindo ração com probiótico. Arquivo Instituto Biológico, São Paulo, v.71, p. 1-1749, 2004. Suppl.

TRALDI, A.B.; OLIVEIRA, M.C.; DUARTE, K.F.; MORAES, V.M.B. Avaliação de probiótico na dieta de frangos de corte criados em cama nova e reutilizada. Revista Brasileira de Zootecnia, Viçosa, MG, v. 36, n.3, p.660-665, maio/jun. 2007. Disponível em:

<http://www.scielo.br/scielo.php?script=sci_arttext\&pid=S1516-35982007000300020>. Acesso em: 20 jan. 2013

UBA - União Brasileira de Avicultura - Relatório 2012. Disponível em: <http://www.uba.org.br〉. Acesso em: 20 jan. 2013. 